\title{
REDAKSIONEEL \\ Predikantevergadering 1985 en die gesag en funksie van die Bybel en die belydenisskrifte
}

In die onderhawige Aflewering van die Hervormde Teologiese Studies is onder andere ' $n$ aantal kort artikels rondom die Kerk se belydenisskrifte en die tema dogmatiese teologie en Bybelse teologie opgeneem. Dit het oorspronklik as voordragte gedien wat tydens byeenkomste van die Interdepartementele Studiegroep: Hermeneutiek gelewer is. Die studie is gedoen met die oog op die Predikantevergadering van die Nederduitsch Hervormde Kerk wat op 16 en 17 September 1985 plaasvind en oor die gesag en funksie van die Bybel en die belydenisskrifte handel. Die twee referate wat op die vergadering deur proff $A D$ Pont en AG van Aarde gehou sal word, sal in die volgende Aflewering gepubliseer word. Sommige van die genoemde kort voordragte en ook ander studiestukke wat vir die predikante van die Kerk as voorafstudiemateriaal kan dien, is reeds in Die Hervormer se Teologiese rubriek gepubliseer. Hierdie artikels is:

PELSER, GMM 1984. Wisselwerking tussen kansel en kateder: Die kateder, Die Hervormer November 1984, bl 16 en 14.

VAN AARDE, AG 1985. Die Skrif: Verdieping in die Reformatoriese grondstellings binne Hervormde teologie, Die Hervormer April 1985, bl 16.

VAN WYK, DJC 1985. Wat is die Kerk se belydenis? Die Hervormer Mei 1985, bl 16.

VAN AARDE, AG 1985. Hervormde teologie, hermeneutiek en die belydenisskrifte, Die Hervormer Junie 1985, bl 16.

VAN DER WESTHUIZEN, HG 1985. Kerk en belydenisskrifte, Die Hervormer Julie 1985, bl 16.

OBERHOLZER, JP 1985. Die teksgeskiedenis van die Heidelbergse Kategismus: 'n Oorsig, Die Heroormer Augustus 1985, bl 16.

Naas die bogenoemde artikels, is in die Hervormde Teologiese Studies, Jaargang 38, Aflewering 2 en 3 en Jaargang 41, Aflewering 1 voordragte gepubliseer wat in die besonder onderskeidelik oor die kerklike bely- 
denis en Skrifgesag handel. Eersgenoemde is voor die Kerkhistoriese Genootskap van die Nederduitsch Hervormde Kerk gelewer en laasgenoemde voor die Fakulteit se Interdepartementele Studiegroep: Hermeneutiek. Die Fakulteit vertrou dat hierdie navorsingsresultate vir die predikante van die Kerk as 'n bron van stimulerende nadenke oor 'n aktuele en belangrike saak in die Kerk en sy teologie kan dien.

Die ander bydraes in die onderhawige Aflewering is referate wat tydens die kongres van die Kerkhistoriese Genootskap in November 1984 en dié van die Hervormde Teologiese Vereniging in Junie 1985 gehou is. 